\title{
Single incision laparoscopic surgery for Meckel's diverticulum in an adult
}

\author{
Simon Rajendran, ${ }^{1}$ Syed Ali Naqi ${ }^{2}$
}

${ }^{1}$ Department of Surgery, Royal College of Surgeons, Dublin, Ireland

${ }^{2}$ Department of Surgery, Beaumont Hospital, Dublin, Ireland

\section{Correspondence to}

Dr Simon Rajendran, simonrajendran@gmail.com

Accepted 3 May 2014

\section{DESCRIPTION}

A 64-year-old man presented with right-sided abdominal pain. CT demonstrated an inflamed Meckel's diverticulum (MD) (figure 1). Single-incision laparoscopy (SILS) was performed (figure 2) and MD was identified and exteriorised. Extracorporeal resection and anastomosis of small bowel containing MD was performed. The patient recovered well and was discharged home 2 days later.

$\mathrm{MD}$, a true congenital diverticulum, is the most common malformation of the gastrointestinal tract and is present in approximately $2 \%$ of the population. It was named after Johann Meckel, who described the omphalovestigial embryological origin in 1809. The most common presenting symptoms are rectal bleeding, intestinal obstruction, volvulus, intussusception and abdominal pain. Technetium$99 \mathrm{~m}$ pertechnetate scintigraphy is the investigation of choice in children while CT is diagnostic in adults. Treatment options are diverticulectomy or ileal resection by open or laparoscopic techniques. SILS is a new modality which aims to reduce the scars of standard laparoscopy, offering a better cosmetic outcome with reduced incisional pain. ${ }^{1}$ It also potentially reduces adhesion formation, port-site infections, hernias and enhances the recovery time. The
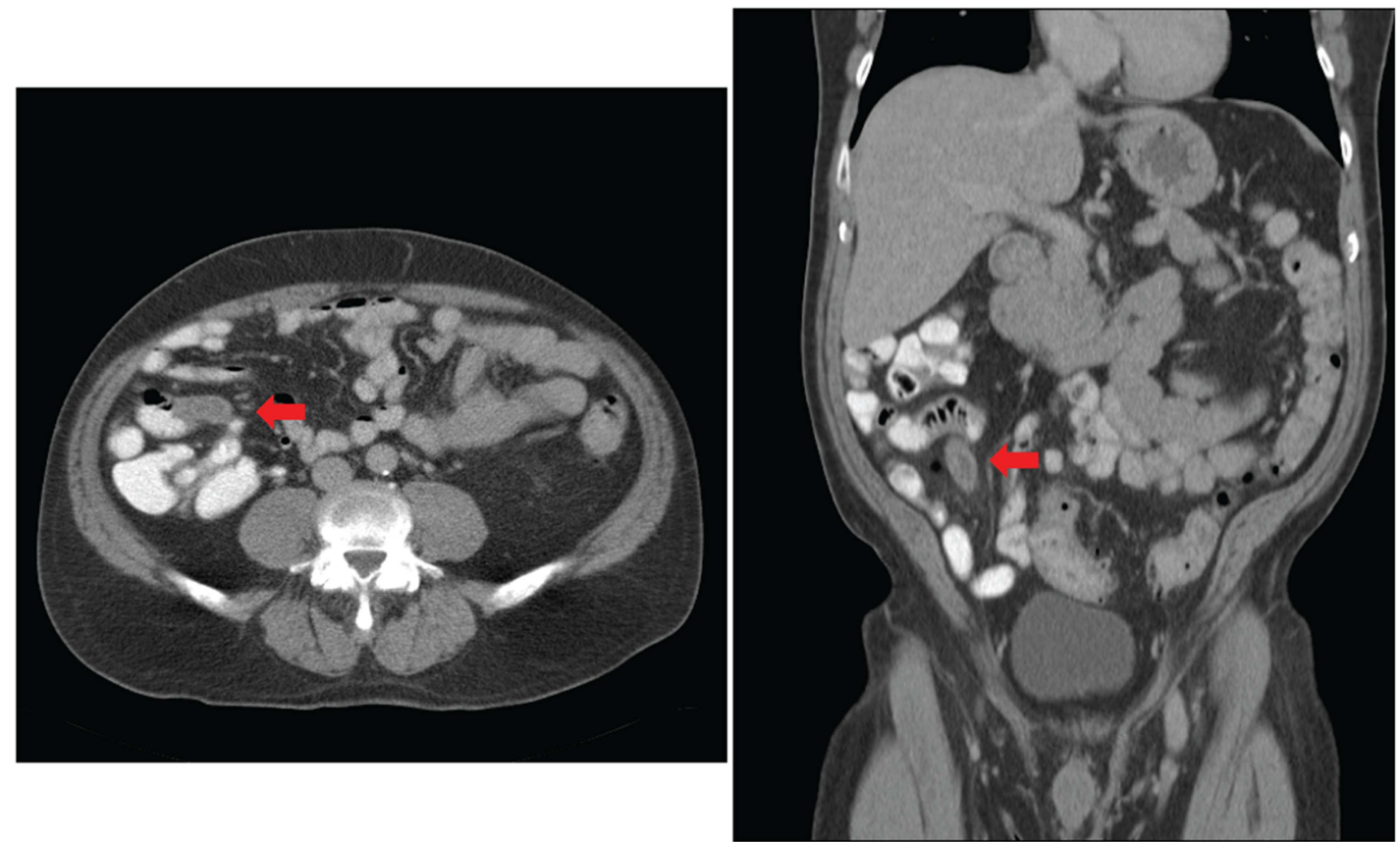

Figure 1 CT images demonstrating inflamed Meckel's diverticulum (MD) (red arrow).
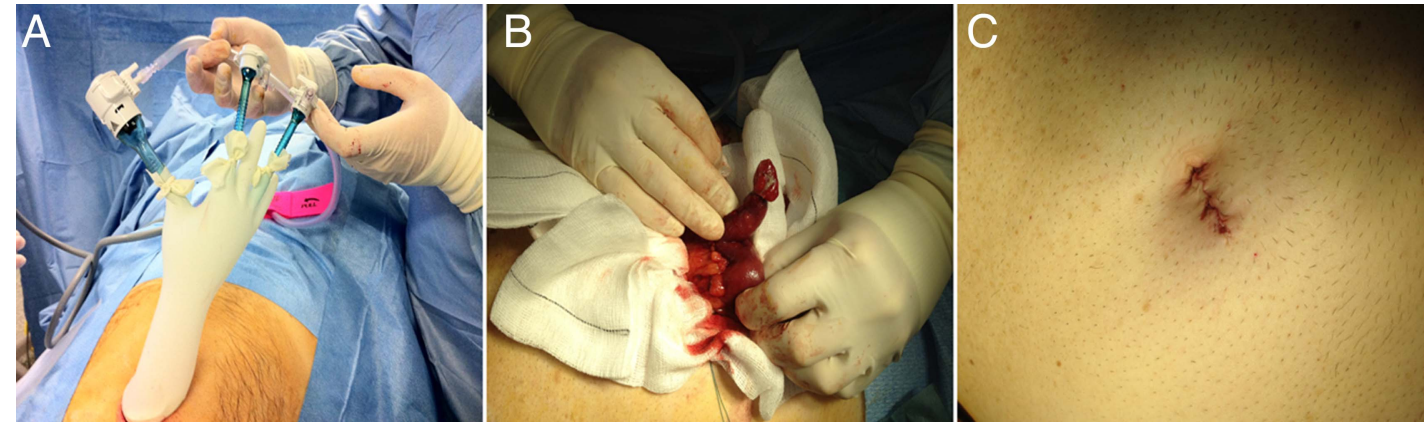

Figure 2 Intraoperative image demonstrating (A) the glove port technique which uses a sterile glove for the insertion of three standard ports into three fingers of the glove before creation of a pneumoperitnoeum. (B) Exteriorised ileum containing MD. (C) Single $2.5 \mathrm{~cm}$ infraumbilical scar. 
glove port technique offers an economically favourable option. It permits the access of multiple standard laparoscopic instruments through a single opening in the umbilicus (figure 2). The main challenges are technical (loss of triangulation, clashing of instru-

\section{Learning points}

- Meckel's diverticulum (MD) is the most common malformation of the gastrointestinal tract and is present in approximately $2 \%$ of the population.

- The most common presenting symptoms are painless rectal bleeding, intestinal obstruction, volvulus, intussusception and abdominal pain.

- Single incision laparoscopy is feasible, safe and cosmetically advantageous to standard laparoscopy for the treatment of MD in an adult. ments and lack of manoeuvrability) resulting in a significant longer learning curve and increased operative time. ${ }^{2}$ We demonstrate that SILS is feasible, safe and cosmetically advantageous ${ }^{3}$ to standard laparoscopy for the treatment of MD in an adult.

Contributors All authors have contributed to the management of the patient and drafting the manuscript. They have read and approved the final manuscript and declare they have no competing interests.

Competing interests None.

Patient consent Obtained.

Provenance and peer review Not commissioned; externally peer reviewed.

\section{REFERENCES}

1 Bresadola F, Pasqualucci A, Donini A, et al. Elective transumbilical compared with standard laparoscopic cholecystectomy. Eur I Surg 1999;165:29-34.

2 Ali S, Moftah M, Ajmal N, et al. Single port-assisted fully laparoscopic abdominoperineal resection (APR) with immediate V-RAM flap reconstruction of the perineal defect. Updat Surg 2012;64:217-21.

3 Rao PP, Rao PP, Bhagwat S. Single-incision laparoscopic surgery-current status and controversies. J Minim Access Surg 2011;7:6-16

Copyright 2014 BMJ Publishing Group. All rights reserved. For permission to reuse any of this content visit http://group.bmj.com/group/rights-licensing/permissions.

BMJ Case Report Fellows may re-use this article for personal use and teaching without any further permission.

Become a Fellow of BMJ Case Reports today and you can:

- Submit as many cases as you like

- Enjoy fast sympathetic peer review and rapid publication of accepted articles

- Access all the published articles

- Re-use any of the published material for personal use and teaching without further permission

For information on Institutional Fellowships contact consortiasales@bmjgroup.com

Visit casereports.bmj.com for more articles like this and to become a Fellow 